\title{
IMPROVING THE ABILITY OF MATHEMATIC CONNECTION AND SELF-CONFIDENCE'S STUDENT OF JUNIOR HIGH SCHOOL THROUGH PROBLEM-BASED LEARNING
}

\author{
Ade Nur $^{1}$, Euis Eti Rohaeti ${ }^{2}$, Rippi Maya ${ }^{3}$ \\ 1, 2, 3 IKIP Siliwangi, Cimahi \\ ${ }^{1}$ SMP Negeri 38 Bandung \\ 12adenurfebrianita@gmail.com, ${ }^{2}$ 22rht@yahoo.com, 3rippimaya@gmail.com \\ Received: Jul 16 ${ }^{\text {th }}$, 2018; Accepted: Sep 28 ${ }^{\text {th }}, 2018$
}

\begin{abstract}
This study aims to examine the achievement, improvement of the ability of mathematical connections and confidence of students through problem-based learning model (PBL). The population is all students of $7^{\text {th }}$ grade from one of SMP Negeri in Bandung. Samples were taken at random class. Among the eleven classes, two classes were selected as an experimental class (VII-K) and a control class (VII-B). The instruments consist of a test instruments (math connection ability) and a non-test instruments. The instrument of test is a set of questions to measure students' mathematical connection ability. While non-test instruments were a scale of students' self-confidence, and the scale of student opinions on PBL. Research shows that there is a difference in achievement, improvement of the ability of mathematical connections and confidence of students whose learning using PBL with the learning using ordinary learning in terms of the initial ability level of students. There is no interaction between the PBL and the student's initial ability level to generate mathematical connections and students' self-confidence. In addition there is a correlation between the ability of mathematical connections and students' self confidence in the classroom that uses the PBL as well as in the classroom using ordinary learning.
\end{abstract}

Keywords: Mathematical Connection, Self Confidence, Problem Based Learning

\begin{abstract}
Abstrak
Penelitian ini bertujuan untuk menelaah pencapaian dan peningkatan kemampuan koneksi matematik serta kepercayaan diri siswa melalui model pembelajaran berbasis masalah. Populasi dalam penelitian ini adalah seluruh siswa kelas VII satu SMP Negeri di Kota Bandung. Sampel diambil secara acak kelas, dari sebelas kelas diperoleh dua kelas yaitu VIIK sebagai kelas eksperimen dan VII-B sebagai kelas kontrol. Instrumen utama dalam penelitian ini terdiri atas dua jenis instrumen, yaitu instrumen tes dan instrumen non tes. Instrumen dalam bentuk tes berupa seperangkat soal tes untuk mengukur kemampuan koneksi matematik siswa. Sedangkan instrumen non tes berupa skala mengenai kepercayaan diri siswa, dan skala pendapat siswa terhadap pembelajaran berbasis masalah. Penelitian menunjukkan bahwa pencapaian dan peningkatan kemampuan koneksi matematik dan kepercayaan diri siswa yang pembelajarannya menggunakan model pembelajaran berbasis masalah terdapat perbedaan dengan yang pembelajarannya menggunakan pembelajaran biasa ditinjau dari tingkat kemampuan awal siswanya. Tidak terdapat interaksi antara model pembelajaran berbasis masalah dan tingkat kemampuan awal siswa dalam menghasilkan koneksi matematik dan kepercayaan diri siswa. Selain itu terdapat korelasi antara kemampuan
\end{abstract}


308 Nur, Rohaeti \& Maya, Improving the Ability of Mathematic Connection and Self-

Confidence's Student of Junior High School Through Problem Based Learning

koneksi matematik dan kepercayaan diri siswa baik di kelas yang menggunakan model pembelajaran berbasis masalah maupun di kelas yang menggunakan pembelajaran biasa.

Kata Kunci: Koneksi Matematik, Kepercayaan Diri, Berbasis Masalah

How to Cite: Nur, A., Rohaeti, E.E., Maya, R. (2018). Improving the Ability of Mathematic Connection and Self-Confidence's Student of Junior High School Through Problem Based Learning. JIML, 1 (3), 307-311.

\section{INTRODUCTION}

The purpose of mathematics learning according to the National of Council Teachers of Mathematics (NCTM [National Council of Teacher of Mathematics], 2000) is to develop mathematical ability: problem solving, reasoning and verification, communication, connection, and representation. Permana \& Sumarmo (2007) argued that mathematics learning should prioritize the development of students' mathematical power which includes: the ability to dig, to construct conjecture and to reason logically, to solve problems that are not routine,to communicate mathematically and link mathematical ideas with other intellectual activities (mathematical connections ). Based on the results of the study found that communication skills and mathematical connections of students still need to be improved. (Ruspiani, 2000) and (Lestari, 2014) revealed that students' ability in mathematical connection was in low and medium categories. The lowest ability is in the ability of connections between mathematical topics. The low level of interconnected connections between topics, compared to mathematical connections with other disciplines and real-world connections, is partly because of the many mathematical topics that must be associated with problem solving and thus require a high range of thinking. While in connection with the real world, the main problem is the difficulty in making mathematical models.

In addition to mathematical connections, affective abilities also greatly affect student learning outcomes. One of the affective abilities that affect the achievement of mathematics learning outcomes is self confidence. Confidence is an attitude that arises from the desire to manifest itself to act and succeed. The phrase can be interpreted that if the students have high confidence, then certainly his curiosity must be high and student involvement in the learning process will be maximized. From the description above, the ability of mathematical connections and self-confidence of students are some factors that can determine the success of student learning in learning mathematics. The diversity of learning models requires educators to be more precise in choosing learning models and various approaches in the classroom, in order to maximize the results.

With the method of lecturing involvement of students in the learning process is very limited, consequently the ability of mathematical connections and self confidence of junior high school students to be less satisfactory. That's what drives writers to apply problem-based learning models. Meanwhile, Arends (Trianto, 2007: 68) states that: "Problem-based learning model is a learning approach in which students do authentic problems with the intention to develop their own knowledge, develop inquiry and higher-order thinking, develop selfreliance and trust self".

\section{METHOD}

The research method used in this research is quasi experiment (Ruseffendi, 2005). The research design used in this research is the pretest-postes design of the control group, where in 
this study there are two groups namely the control group and the experimental group which each group is given pretest and postes. Selection of control group and experimental group was conducted by non-random subjects. Furthermore, the differences in the results of pretest and postes between the experimental group and the control group are compared. The research design is as follows:

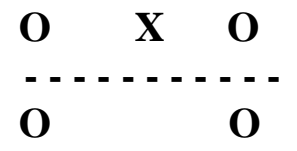

Description:

$\mathrm{O} \quad$ : Pretest and Postest of Mathematical Connection

$\mathrm{X} \quad$ : Mathematics learning using Problem Based Learning model

. . . . . . : : The sampling is not random

The population in this study is the seventh grade students from one of the State Junior High School in Bandung. Sampling in this study were students of two classes of VII assigned randomly to the class.

\section{RESULTS AND DISCUSSION}

\section{Results}

The results of the study for mathematical connection ability are as follows:

Tabel 1. Postest and N-Gain Analysis for Mathematical Connection Ability

\begin{tabular}{|c|c|c|c|c|c|c|c|c|}
\hline \multirow[b]{2}{*}{ Testing Data } & \multirow[b]{2}{*}{ Class } & \multirow[b]{2}{*}{ Normality } & \multirow[b]{2}{*}{ Homogenitas } & \multicolumn{3}{|c|}{ Two way Anova } & \multicolumn{2}{|c|}{ Interaction } \\
\hline & & & & Method & TKAS & $\begin{array}{l}\text { Metode } \\
\text { *TKAS }\end{array}$ & Scheffe & Info \\
\hline \multirow{2}{*}{ Postest } & PBL & 0.200 & 0.650 & \multirow{2}{*}{0.000} & \multirow{2}{*}{0.700} & \multirow{2}{*}{0.576} & \multirow{2}{*}{ - } & \multirow{2}{*}{$\begin{array}{c}\text { No there } \\
\text { is }\end{array}$} \\
\hline & Convensional & 0.101 & 0.650 & & & & & \\
\hline \multirow{2}{*}{ N-Gain } & PBL & 0.083 & 0.864 & \multirow{2}{*}{0.000} & \multirow{2}{*}{0.932} & \multirow{2}{*}{0.966} & \multirow{2}{*}{ - } & \multirow{2}{*}{$\begin{array}{l}\text { No there } \\
\text { is }\end{array}$} \\
\hline & Convensional & 0.200 & 0.864 & & & & & \\
\hline
\end{tabular}

The results showed that the achievement and improvement of mathematical connection ability of students whose learning using problem-based learning model is better than the learning using normal learning in terms of the initial ability level of students and there is no interaction between the problem-based learning model and the level of initial ability of students in generating the ability of mathematical connection.

Based on the result of the two-lane anova test proved that the most important role in the achievement and improvement of mathematical connection ability is the learning model is the problem-based learning model but the initial ability level of students is not so instrumental in achieving and improving students' mathematical connection ability. The results of research for students' self-confidence are as follows: 
310 Nur, Rohaeti \& Maya, Improving the Ability of Mathematic Connection and SelfConfidence's Student of Junior High School Through Problem Based Learning

Tabel 2. Data Analysis Students' Self-Confidence Scale

\begin{tabular}{ccccc}
\hline \multirow{2}{*}{ Testing Data } & Class & Normality & Homogeneity & $\begin{array}{c}\text { Two-point } \\
\text { Differences }\end{array}$ \\
\hline $\begin{array}{c}\text { Skala } \\
\text { Kepercayaan } \\
\text { Diri }\end{array}$ & Eksperimen & 0.092 & 0.517 & 0.026 \\
\cline { 2 - 3 } & Kontrol & 0.085 & 0.026 & \\
\hline
\end{tabular}

The results showed that students' self-confidence learning using problem-based learning model is better than the learning using ordinary learning in terms of initial ability level of students. The results of the research for Regression and Correlation Analysis are as follows:

Tabel 3. Regression and Correlation

\begin{tabular}{|c|c|c|c|c|c|c|c|}
\hline Asosiasion & \multicolumn{2}{|c|}{ Normality } & Regression & Correlation & Guilford & Significance & Info. \\
\hline \multirow{2}{*}{$\begin{array}{l}\text { Connection- } \\
\text { Self } \\
\text { Confidence }\end{array}$} & Connection & 0.200 & \multirow[b]{2}{*}{0.037} & \multirow[b]{2}{*}{0.019} & \multirow[b]{2}{*}{ Low } & \multirow[b]{2}{*}{ There is } & \multirow[b]{2}{*}{ There is } \\
\hline & $\begin{array}{c}\text { Self } \\
\text { Confidence }\end{array}$ & 0.092 & & & & & \\
\hline
\end{tabular}

The results showed that there is a connection between the ability of mathematical connections and students' self-confidence in the classroom using the problem-based learning model as well as in the classroom using ordinary learning.

\section{Discussion}

Results of data processing show that the problem-based learning model affects the ability of students' mathematical connections. Learning using problem-based learning model helps in achieving and improving students' mathematical connection ability.

Meanwhile, based on TKAS, there is no significant difference between the mathematical connection ability of students in certain TKAS. Problem-based learning model affects students' self-confidence. Similarly, students 'mathematical connection ability to students' self-confidence. Because there is a significant influence of students 'mathematical connection ability to students' self-confidence then proceed to the correlation test.

Students who are the subject of this research generally have a positive attitude toward learning mathematics. This problem-based learning model can contribute to the development of students' mathematical connection skills compared to ordinary learning. This can be known from students' answers that express more like learning methods as they are given and they are helped to be more active. In addition, students are more enthusiastic and passionate about working on problems on LKS and postest questions.

\section{CONCLUSION}

Based on the analysis and discussion of the results, obtained the following conclusion: achievement and improvement of mathematical connection ability of students whose learning using problem-based learning model is significantly better than the learning using ordinary learning viewed from the initial ability of students, students' self-confidence learning using learning-based model the problem is significantly better than that of learning using regular learning in terms of the initial ability of students, there is a link between the ability of mathematical connections and confidence of students both in the classroom using the 
problem-based learning model and in the classroom using ordinary learning, there is no interaction between the model of learning problem-based and initial ability level of students in generating mathematical connection ability and students' self-confidence.

The description of student performance during the problem-based learning model shows the students 'involvement either individually or in group collaboration to construct new knowledge that must be possessed by students, so as to improve the students' mathematical connection and self confidence. Problem-based learning causes students to be more active and enthusiastic in learning activities. They are very enthusiastic in reviewing the LKS and in solving the problems given. While the learning activities of students with ordinary learning tend to be passive, both in reviewing the LKS and in resolving the questions given researchers. They look bored with the material given and easily give up when solving the problems. The picture of student performance in the problem-based learning class does not experience significant difficulties when doing mathematical connection problems. However, many students in ordinary learning classes are unable to construct the expected mathematical model.

\section{REFERENCES}

Lestari, K. E. (2014). IMPLEMENTASI BRAIN-BASED LEARNING UNTUK MENINGKATKAN KEMAMPUAN KONEKSI DAN KEMAMPUAN BERPIKIR KRITIS SERTA MOTIVASI BELAJAR SISWA SMP. JUDIKA (JURNAL PENDIDIKAN UNSIKA), 2(1). Retrieved from https://journal.unsika.ac.id/index.php/judika/article/view/120

NCTM [National Council of Teacher of Mathematics]. (2000). Princiles and Standards for School Mathematics. Virginia: NCTM.

Permana, Y., \& Sumarmo, U. (2007). Mengembangkan Kemampuan Penalaran dan Koneksi Matematik Siswa SMA Melalui Pembelajaran Berbasis Masalah. Educationist, I(2), $116-123$.

Ruseffendi, E. . (2005). Dasar Penelitian Pendidikan dan Bidang Non Eksakta Lainnya. Bandung: Tarsito.

Ruspiani. (2000). Kemampuan Siswa dalam Melakukan Koneksi Matematika. UPI Bandung. Trianto. (2007). Model-model Pembelajaran Inovatif Berorientasi Konstruktivistik. Jakarta: Prestasi Pustaka. 